Vol 2 No 1 Juli 2021

Jurnal AlphaEuclidEdu

Received:15/04/2021; Resived:24/06/2021; Accepted:12/07/2021

\title{
KEMAMPUAN REPRESENTASI MATEMATIS SISWA PADA MATERI SEGITIGA
}

\author{
${ }^{1}$ Monika Sari, ${ }^{2}$ Edy Yusmin, ${ }^{3}$ Ahmad Yani T \\ 1,2,3Pendidikan Matematika FKIP Universitas Tanjungpura, Pontianak, Indonesia \\ Email: sarimonika48@gmail.com
}

\begin{abstract}
The mathematical representation ability referred to in this study is the ability to express mathematical ideas or ideas to solve a problem with various mathematical representations of visual forms (pictures) and verbal forms (writing).This type of research is descriptive with a qualitative approach which aims to describe systematically the ability of visual mathematical representations and the ability of verbal mathematical representations. The data collection technique in this study was carried out using essay. Test questions were given to student an grade VIII A at SMP Negeri 1 Mandor, where there were three groups, namely the upper, middle, and lower group. Students who will be interviewed are selected based on the representation ability test scores where only two students will represent for each group.The results showed that the ability of visual mathematical representation when given verbal form questions to answer indicators using pictures was in the percentage of students' average score $66.67 \%$ and the ability of verbal mathematical representation if given visual questions, for the answer indicator using words is in the percentage of the student's average score of 33.33\%. Students still have difficulty with verbal representation if given a visual form.
\end{abstract}

Keywords: visual representation, verbal representation and trangle material

\section{Pendahuluan}

Tujuan dari pembelajaran matematika sesuai dengan Pemendikbud Nomor 22 tahun 2016 kurikulum 2013 yaitu: Memahami konsep matematika, mendeskripsikan bagaimana keterkaitan antara konsep matematika dan menerapkan konsep atau logaritma secara efisien, luwes, akurat, dan tepat. Mengkomunikasikan argumen atau gagasan dengan gambar, diagram, table, simbol, atau media lainnya agar dapat memperjelas permasalahan atau keadaan.

Ada lima standar pembelajaran matematika yang harusnya dikuasai siswa menurut NCTM (2000:7) yaitu: 1). Belajar untuk memacahkan masalah. 2). Belajar untuk bernalar. 3) belajar untuk berkomunikasi. 4). Belajar untuk mengaikan ide. 5) belajar untuk merepresentasikan. Kemampuan-kemampuan diatas sering disebut dengan daya matematis. Satu diantar kelima standar proses pembelajaran matematika yang harus dikuasi siswa yaitu kemampuan untuk mereprsentasikan yang harus dimiliki setiap siswa. Kemampuan representasi matematis sangat penting dimiliki setiap siswa karena kemampuan representasi sangat membantu siswa dalam memahami konsep matematika. Kemampuan representasi matematis tidak hanya memudahkan siswa dalam mengkomunikasikan ide-ide matematis, namun juga sangat mendukung siswa dalam memahami dan mengaitkan antar konsep. Hudiono (2007:4) kemampuan representasi dapat mendukung siswa dalam memahami konsep- konsep matematika yang dipelajari dan keterkaitannya, untuk mengkomunikasikan ide-ide matematik siswa, lebih mengenal keterkaitan (koneksi) diantar konsep-konsep. 
Dalam proses pembelajaran matematika ketika siswa dapat mengungkapkan ideide matematika, baik masalah, solusi, pernyataan, definisi dan sebagainya ke dalam bentuk visual (gambar) maupun kata-kata (verba) maka siswa tersebut dikatakan mampu merepresentasikan, yang mana nantinya akan memperlihatkan hasil dari pemikiran mereka. Pada saat siswa dihadapi pada masalah matematioka dalam proses pembelajaran dikelas, siswa berusaha memahami masalh yang ada dan siswa dapat menyelesasian permasalahan dengan cara-cara yang siswa ketahui. Cara-cara yang siswa gunakan sangat terkait dengan pengetahuan yang sudah siswa milki sebelumnya yang berhubungan dengan masalh yang disajikan, satu diantara banyaknya upayah yajngt dapat dilakukan siswa yaitu dengan membuat representasi dari masalh yang dihadapi dalam proses pembelajaran matematika (Yurianti et al., 2014); (Yunika et al., 2020).

Dari hasil wawancara kepada satu guru matematika di SMP Negeri 1 Mandor didapat informasi yaitu, didalam proses pembelajaran matematika dikelas untuk hasil belajar siswa pada materi segitiga, sebagian besar nilai yang siswa peroleh belum mencapai Kriteria Ketuntasan Minimal (KKM) yang ditetapkan sekolah tersebut. Rendahnya hasil belajar pada materi segitiga ini disebabkan beberapa alasan diantaranya, siswa masih tidak tepat dalam menggunakan representasi pada materi segitiga, hal tersebut dapat dilihat dari siswa yang kurang mampu dalam menerjemahkan kalimat matematika kedalam bentuk gambar, ataupun sebaliknya, dikarena kan siswa tidak memahami konsep yang ada. Hal tersebut menunjukan bahwa kemampuan representasi matematis sangat dibutuhkan dalam menyelesaikan permasalahan matematika yang ada (Andriyanto et al., 2016); (Ulya, 2020).

\section{Metode Penelitian}

Adapun tujuan dilakukan penelitian ini adalah untuk mendekripsikan tentang kemampuan representasi matematis siswa pada materi segitiga di SMP Negeri 1 Mandor. Berdasarkan tujuan dari penelitian ini, maka metode yang sesuai dengan penelitian ini adalah metode deskriptif dengajn pendekatan kualitatif. Menurut Arikunto (2010:3) metode deskritif yang dimaksud untuk menyelidiki keadaan, kondisi atau hal lain-lain yang sudah disebutkan, yang hasilnya dipaparakan dalam bentuk laporan. Menurut Nawawi (2012:67) metode deskriptif dapat diartikan sebagai prosedur pemecahan masalah yang diselidiki dengan menggambarakan keadaan subyek atau objek penelitian (seseorang, lembaga, masyarakat dan lain-lain) pada saat sekarang berdasarkan fakta-fakta yang tampak, atau sebagaimana adanya. Bentuk penelitian yang digunakan dalam penelitian ini adalah penelitian studi kasus. Menurut Arikunto (2013:185) penelitian studi kasus adalah suatu penelitian yang dilakukan secara intensif terinci dan mendalam terhadap suatu organisasi, lembaga atau gejala tertentu. Subjek penilitian ini adalah siswa kelas VIII A di SMP Negeri 1 Mandor, berdasarkan pertimbangan dari guru mata pelajaran matematika. Penelitian ini ditentukan dengan teknik purposive sampling. Arikunto (2013:183) purposive sampling dilakukan dengan cara mengambil subjek bukan didasarkan atas strata, random, atau daerah, tetapi 
didasarkan atas tujuan atau pertimbangan tertentu. Menurut Arikunto (2010:61) ada tiga prosedur dalam penelitian, yaitu: pembuatan rancangan penelitian, pelakasanaan penelitian dan pembuatan laporan penelitian.

Teknik pengumpulan data yang akan digunakan dalam penelitian ini adalah teknik tes dan teknik komunikasi langsung. teknik tes yang digunkana dalam penelitian ini berupa soal tes essay yang berkaitan dengan materi segitiga di SMP. Teknik pengumpulan data pada penelitian ini adalah teknik pengukuran berupa tes tertuis berbentuk essay dan teknik komunikasi langsung berupa wawancar, instumen pada penelitian ini divalidasi oleh satu orang dosen Pendidikan Matemaika FKIP Untan dan satu orang guru SMP dengan hasil bahwa instrument yang digunakan valid (layak digunakan).

Hasil tes dianalisis dengan memberikan skor pada hasil jawaban siswa kemudian menganalisis kemampuan representasi visual dan kemampuan representasi verbal siswa, dilihat dari hasil tes yang diberikan.

\section{Hasil Penelitian dan Pembahasan}

\section{Hasil Penelitian}

Tujuan dari penelitian ini adalah untuk mendeskripsikan bagaimana kemampuan represebntasi visual dan kemampuan representasi verbal siswa pada materi segitiga dimana subjek penelitian ini berjumlah enam orang siswa kelas VIII A yang telah di kelompokkan menjadi tiga kelompok, yaitu kelompok atas, tengah dan bawah berikut ini untuk table 1, hasil skor yang diperoleh siswa:

Table 1. Kemampuan Representasi Matematis Siswa

\begin{tabular}{|c|c|c|c|c|c|}
\hline $\begin{array}{l}\text { Kemampuan } \\
\text { Representasi }\end{array}$ & Kelompok & $\begin{array}{c}\text { Subjek } \\
\text { Penelitian }\end{array}$ & Skor & $\begin{array}{l}\text { Persentase } \\
\text { Rata-rata }\end{array}$ & Katagori \\
\hline \multirow{7}{*}{$\begin{array}{l}\text { Representasi } \\
\text { visual bentuk } \\
\text { soal verbal. }\end{array}$} & \multirow[t]{2}{*}{ Atas } & S1 & 6 dari 6 & $100 \%$ & Sangat tinggi \\
\hline & & $\mathrm{S} 2$ & 5 dari 6 & $83.33 \%$ & Sangat tinggi \\
\hline & \multirow[t]{2}{*}{ Tengah } & S3 & 4 dari 6 & $66,66 \%$ & Tinggi \\
\hline & & S4 & 4 dari 6 & $66,66 \%$ & Tinggi \\
\hline & \multirow[t]{2}{*}{ Bawah } & S5 & 3 dari 6 & $50 \%$ & Sedang \\
\hline & & S6 & 2 dari 6 & $33,33 \%$ & Rendah \\
\hline & \multicolumn{3}{|c|}{ Total persentase rata-rata siswa } & $66,67 \%$ & Tinggi \\
\hline \multirow{7}{*}{$\begin{array}{l}\text { Representasi } \\
\text { verbal bentuk } \\
\text { soal visual }\end{array}$} & \multirow[t]{2}{*}{ Atas } & $\mathrm{S} 1$ & 4 dari 6 & $66,6 \%$ & Tinggi \\
\hline & & $\mathrm{S} 2$ & 3 dari 6 & $50 \%$ & Sedang \\
\hline & \multirow[t]{2}{*}{ Tengah } & S3 & 2 dari 6 & $33,33 \%$ & Rendah \\
\hline & & S4 & 1 dari 6 & $16,66 \%$ & Sangat rendah \\
\hline & \multirow[t]{2}{*}{ Bawah } & S5 & 1 dari 6 & $16,66 \%$ & Sangat rendah \\
\hline & & S6 & 1 sari 6 & $16,66 \%$ & Sangat rendah \\
\hline & \multicolumn{3}{|c|}{ Total persentase rata-rata siswa } & $\mathbf{3 3}, \mathbf{3 3} \%$ & Rendah \\
\hline
\end{tabular}

\section{Pembahasan}

Penelitian tentang kemampuan representasi matematis siswa pada materi segitiga di SMP Negeri 1 Mandor dilaksanakan pada tanggal 12 November 2020. Penelitian ini 
dilakuklan secara daring karena saat penelitian negara indeonesia terpapar virus Covid19, jadi belajar dan pembelajaran disekolah dilakukan secara daring. soal yang diberikan berbentu uraian dimana terdiri dari dua soal berbentuk visual dan dua soal berbentuk verbal. Berikut hasil analisi dari setiap soal mengenai kemampuan representasi matematis siswa pada materi segitiga diperoleh kemampuan dari setiap kelompok siswa berbeda-beda berikut pembahasan yang akan dibahas sesuai dengan indikator kemampuan representasi matematis visual dan kemampuan representasi matematis verbal.

\section{Kemampuan Representasi Matematis Visual Siswa Jika Diberikan Soal Bentuk Representasi Verbal Materi Segitiga.}

Berdasarkan dari hasil penelitian, maka di peroleh informasi untuk siswa dari kelompok atas dengan subjek S1 menjawab soal dengan skor sempurna. Soal nomor 1 mendapat skor 3 dari 3 dan untuk soal nomor 3 subjek S1 mendapat skor 3 dari 3. Siswa subjek S1 didukung dengan hasil wawancara siswa mengalami sedikit kesulitan dalam menyelsaikan soal bentuk verbal ke visual ini dikarenakan siswa subjek S1 paham dengan permintaan soal. Maka dari itu siswa subjek S1 mendapat skor 6 dari 6. Siswa kelompok atas yang lainnya subjek S2 dari soal no.1 mendapat skor 2 dari 3 dan soal no. 3 mendapat skor 3 dari 3 hasil wawancara kepada subjek S2, sudah memahami permintaan soal sehingga subjek S2 mendapat 5 dari 6.

Siswa dari kelompok tengah denagan kode S3 dalam soal no.1 mendapat skor 2 dari 3 sedangkan soal no.3 subjek S1 mendapat skor 2dari 4. Dan saat diwawancarai subjek S3, mengaku kurang memahami soal no.3. Jadi skor yang didapatkan siswa subjek S3 yaitu 4 dari 6. Siswa dari kelompok tengan dengan kode S4 dapat mevisualisasikan soal bentuk verbal ke visual dengan benar namun masih kurang lengkap. Pada soal no. 1 subjek S4 mendapat skor 2 dari 3 dan pada soal no.3 subjek S4 mendapat skor yang sama dengan subjek S3. Jadi skor yang diperoleh subjek S4 yaitu 4 dari 6.

Siswa dari kelompok bawah dengan kode S5 dalam menjawab soal no. 1 mendapat skor 1 dari 4 dan jawaban soal no. 3 mendapat skor yang sama dengan skor soal no. 1 , skor yang diperoleh subjek S5 mengatakan kurang memahami soal dengan baik dari itu subjek S5 mendapat skor 2 dari 8. Siswa dari kelompok bawah selanjutnya dengan kode subjek S6 medapat skor 2 dari 1 untuk soal no. 1 dan mendapat skor 1 dari 3 untuk soal no.3. siswa subjek S6 memahami soal no.1 dan no.3 hanya saja kurang memahami dengan sifat-sifat segitiga, sehingga hanya menggambarkan sebisanya. Maka skor yang diperoleh subjek S5 3 dari 6.

Analisis data kemampuan representasi visual bentuk soal verbal, kelompok tinggi untuk subjek S1 dalam katagori sangat tinggi, dan subjek S2 dalam katagori sangat tinggi. Subjek S3 kelompok tengah kemampaun representasi visual bentuk soal verbal dalam katagori tinggi. Subjek S4 kemamapun representasi visual bentuk soal verbal dalam katagori tinggi. Subjek S5 kelompok bawah kemampuan representasi visual bentuk soal verbal dalam katagori sedang. Dan subjek S6 kemampuan representasi visual bentuk soal verbal dalama katagori rendah. 
Dari hasil wawancara kemampuan representasi matematis siswa ternyata masih kesulitan dalam memahami soal tes yang diberikan, ada beberapa siswa yang masih kesulitan menggambarkan sebuah segitiga jika hanya diberikan sifat-sifat segitiganya saja. Sehingga terdapat kesalahan yang siswa tunjukan pada saat membuat gambar. Gambar yang siswa buat masih tidak memenuhi sifat-sifat segitga yang sudah siswa buat siswqa menggambarkan berdasarkan sifat-sifat yang mereka ketahui saja. Kemampuan siswa yang harus siswa lakukan didalam melakukan translasi dari bentuk verbal ke bentuk visual yaitu soal tes dalam bentuk representasi verbal menuntut siswa untuk memahami sifat-sifat segitiga dengan baik, siswa yang kemampuannya kurang dalam mengenal sifat-sifat akan kesulitan di dalam menggambar segitiga. Kemampuan representasi matematis visual dari bentuk soal representasi matematis verbal juga disebabkan tidak terbiasannya siswa untuk mengerjakan soal meggambar segitiga berdasarkan sifat-sifat yang telah diberikan.

\section{Kemampuan Representasi Verbal Siswa Jika Diberikan soal bentuk Representasi Visual Materi Segitiga.}

Siswa kelompok atas dengan kode subjek S1 dapat menjawab soal namun masih kurang memuaskan. Dari soal no.2 subjek S1 mendapat skor 2 dari 3 dan soal no. 4 mendapat skor 2 dari 3. Dari hasil wawancara subjek S1 mengatakan sedikit kesulitan. Jadi subjek S1 mendapat skor 4 dari 6. Siswa dari kelompok ataslainnya dengan kode subjek S2 pada soal no. 2 mendapat skor 2 dari 3 dan soal no. 4 mendapat skor 1 dari 3 subjek S2 mengalami kesulitan ketika menuliskan sifat-sifat soal no. 2 dan no. 4. Siswa subjek S2 masih kurang lengkap dalam meuliskan sifat-sifat segitiga. Jadi subjek S2 memperoleh skor 3 dari 6.

Siswa dari kelompok tengah dengan kode subjek S3menjawab kedua soal pada soal no. 2 subjek S3 mendapat skor 1 dari 3 dan soal no. 4 mendapat skor 1 dari 3. Dari hasil wawancara subjek S3 masih sulit mengolah informamsi dalam bentuk visual. Sehingga sub skor 2 dari 6. Siswa kelompok tengah lainnya dengan kode subjek S4, menjawabab soal kemampuan representasi verbal bentuk soal visual kurang memuaskan. Dari soal no. 2 mendapat skor 0 dari 3 dan soal no. 3 mendapat skor 1 dari 4, dari hasil wawancara subjek S4 masih kurang paham dalam menjelaskan apa yang dimaksud dalam menjawab soal. Dan siswa subjek S4 juga masih kesulitan ketika menjawab soal. Bila di jumlah kan subjek S4 mempeoleh skor 1 dari 6.

Siswa dari kelompok bawah dengan kode subjek S5, subjek S5 menuliskan beberapa jawaban dari soal no.2. dalam soal no. 2 subjek S4 kurang memahami apa yang diminta dalam soal. Dari hasil wawancara yang didapatkan subjek S4 masih tidak terbiasa mengolah informasi jika hanya melihat gambarnya saja. Dari soal no. 2 subjek S4 mendapt skor 1 dari 3 dan soal no.4 medapat skor 0 dari 3. Jadi skor yang diperoleh subjek S4 yaitu 1 dari 6. Siswa dari kelompok bawah lainnya dengan kode subjek S6. subjek S6 menuliskan sifat-sifat segitiga keliru dan tidak sesuai dengan gambar yang diberikan. Soal no. 2 mendapat skor yaitu 0 dari 3 dan soal no. 4 mendapat skor 1 dari 3 . sehingga subjek S6 mendapat nilai yang tidak memuaskan. Hasil wawancra menunukan bahwa subjek S6 mengalami kesulitan seperti tidak paham dan kurang mengerti 
menjawab soal. Maka dari itu subjek S6 mendapat skor 1 dari 6.

Dari hasil wawancara kepada enam orang siswa, diperoleh bahwa siswa masih menggalami kesulitan dalam menuliskan sifat-sifat segiitiga dengan menggunakan bahasanya sendiri, hal tersebut disebabkan siswa masih terpaku dengan menggunakan bahasa atau sifat-sifat segitga yang siswa pelajari atau ketahui sebelumnya. Sehingga Ketika siswa menjawab soal cenderung untuk mengingat yang sudah siswa pelajari seblumnya. Rendahnya kemampuan translasi representasi visual bentuk verbal siswa dikarenakan siswa masih tidak memahami sifat-sifat segitiga, dan juga tidak terbiasanya siswa mengolah sebuah informasi lalau meribah infromasi itu Kembali dari bentuk visual ke bentuk verbal dari hasil pemikiran siswa sendiri.

\section{Kesimpulan dan Saran}

Kesimpulan yang dapat diperoleh setelah melakukan penelitian berdasarkan analisis dan pembahasan yang telah dilakukan, diperoleh kesimpulan bahwa kemampuan representasi matematis siswa dari setiap indikator sebagai berikut: 1) Kemampuan representasi visual bentuk soal verbal S1 dari kelompok atas dalam katagori sangat tinggi subjek S1 dalam menyelesaiakan soal representasi visual bentuk soal verbal memperoleh persentase rata-rata $100 \%$. Sedangkan kemampuan representasi visual bentuk soal verbal subjek S2 dari kelompok atas dalam katagori sangat tinggi dengan persentase $83,33 \%$. Subjek S3 dari kelompok tengah dengan persentase rata-rata $66,66 \%$ dalam kemampuan representasi visual bentuk soal verbal. 2) Kemampuan representasi verbal bentuk soal visual verbal S1 dari kelompok atas dalam katagori tinggi subjek S1 dalam menyelesaiakan soal representasi visual bentuk soal verbal memperoleh persentase rata-rata 66,66\%. Sedangkan kemampuan representasi verbal bentuk soal visual subjek S2 dari kelompok atas dalam katagori sedang dengan persentase rata-rata 50\%. Subjek S3 dari kelompok tengah memperoleh persentase ratarata 33,33\% dalam kemampuan representasi verbal bentuk soal visual. Sehingga kemamuan representasi verbal bentuk soal visual subjek S3 dalam katagori rendah. Kemampuan representasi verbal bentuk soal visual subjek S4 kelompok tengah dalam katagori sangat rendah subjek S4 memperoleh persentase rata-rata 16,66\%.

\section{Saran}

Beberapa saran yang dapat peneliti sampaikan berdasarkan hasil penelitian yang telah dilaksanakan sebagai berikut: 1) Untuk siswa-siswi SMP Negeri 1 Mandor dapat meningkatkan kemampuan merepresentasi matematis agar dapat membuat kreativitas matematika yang lain saat menyelesaikan berbagai persoalan matematika lainnya. 2) Untuk guru matematika diharapkan dapat mempertimbangkan hasil dari penelitian ini untuk dijadikan sebagai satu acuan dalam proses pembelajaran matematika. 3) Sebelum melakukan penelitian, instrument penelitian yang digunakan harus disiapkan dengan matang, untuk alokasi waktu yang gunakan dalam penelitian juga harus dipertimbangkan dengan baik, sehingga pada saat penelitain siswa tidak kekurangan waktu dalam mengerjakan soal tes yang diberikan. 4) Bagi peneliti lainnya disarankan ketika memberikan soal tes kemampuan representasi matematis visual dan verbal soal 
tes yang diberikan sama untuk setiap soal, karna jika beda maka siswa akan kesulitan mengerjakan tes.

\section{Referensi}

Andriyanto, Ahmad, D., \& Sugiatno. (2016). Pengembangan Problem Solvng Matematis Siswa Melalui Pendekatan Metekognitif Di SMP. 1-14.

Arikunto, Suharsimi. (2013). Prosedur Penelitian. Jakarta: Rineka Cipta

Hudiono, B. (2005). Peran Pembelajaran Diskursi Multi Representasi Tehadap Pengembangan Kemampuan Matematik dan Days Representasi Pada Siswa SLTP. Bandung: Disertai UPI.

Hudiono, B. (2007) Representasi dalam Pembelajaran Matematika. Pontianak: STAIN Pontianank Press.

Nawawi, H. 2012. Metode Penelitian Bidang Sosial. Cetakan 13. Yogyakarta: Gadjah Mada University Press.

NCTM (National Council of Teacher of Mathematics). (2000). Priciples and Standars for School Mathematics.NCTM: Resto, Virginia .

Permendikbud. 2016. Peraturan Mentri Pendidikan dan Kebudayaan Republik Indonesia Nomor 24 Tahun 2016. Jakarta. Permendikbud .

Sugiyono, 2015. Metode Penelitian Pendidikan (Pendekatan Kuntitatif, kualitatif dan $R \& D$. Bandung: IKAPI.

Ulya, D. (2020). Pengembangan Bahan Ajar Interaktif Untuk. 1(2), 162-171.

Yunika, V., T, A. Y., \& Suratman, D. (2020). Kemampuan Koneksi Matematis Siswa Dengan Pendekata Looking Back Dalam Materi Aritmatika Sosial.

Yurianti, S., Yusmin, E., \& Nursangaji, A. (2014). Kemampuan Penalaran Matematis Siswa Pada Materi Sistem Persamaan Linear Dua Variabel Kelas X SMA. Jurnal Pendidikan Dan Pembelajaran Khatulistiwa, 3(6), 1. 